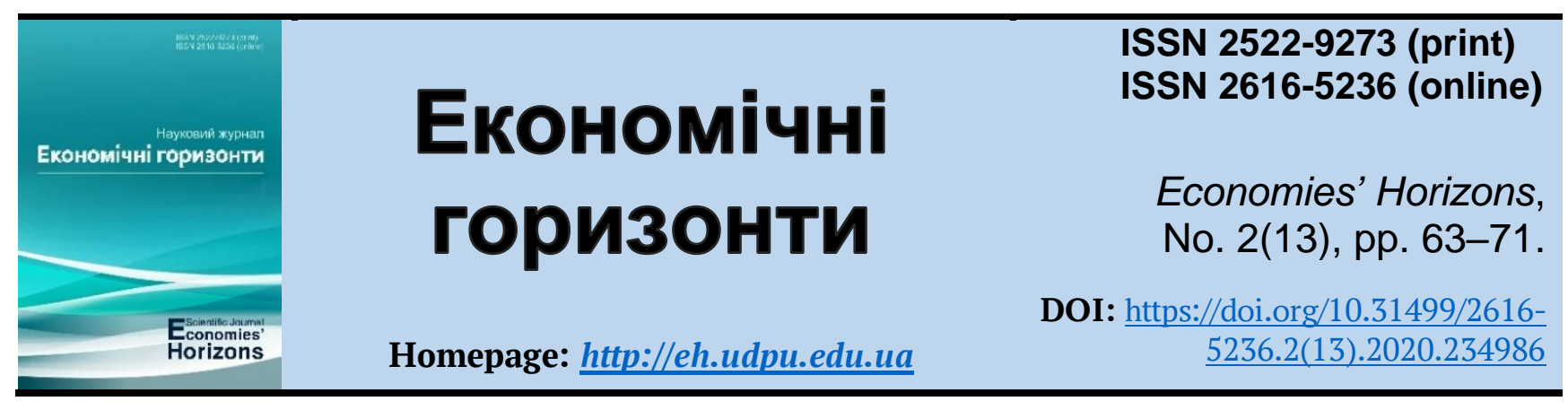

UDC 330.56:656.07

\title{
Business process management in the system of competitive development of territories: Theoretical aspect
}

\author{
Iryna I. Nadtochii ${ }^{1}$, Cand. Ec. Sc., Associate Professor
}

Received: 10 May 2020

Accepted: 14 June 2020

\begin{abstract}
Nadtochii, I. I. (2020), "Business process management in the system of competitive development of territories: Theoretical aspect”, Economies' Horizons, no. 2(13), pp. 6371, doi: https://doi.org/10.31499/2616-5236.2(13).2020.234986
\end{abstract}

Abstract. The purpose of the article is to study the theoretical foundations of business process management in the system of competitive development of territories. Methodology. The theoretical and methodological basis of the study are the scientific works of scientists in the study of business process management in the system of competitive development of territories. To achieve the goal set in the work, the following research methods were used: theoretical generalization - features and forms of competition of regions; methods of positive and normative analysis - to define the concept of "competitive potential of the region". Results. It is determined that the problems of interregional competition are high and constantly growing, there are many white spots in the theory of understanding the features and methods of assessing the competitive properties and competitive potential of individual territorial development entities, unclear ways and means to use assessments of competitive attractiveness in management. The ways of development of territorial competition and methods of stimulating regions to increase their competitive attractiveness are insufficiently studied. It is proved that the scientific and innovative potential and mechanisms of their support are the most modern and promising source of competitive advantages. It is determined that the most developed countries are trying to increase their scientific and innovative potential, because it is a factor in creating fundamentally new products to upgrade and improve the quality of products, inventing new technologies to increase productivity and reduce resource costs. The scientific and innovative potential of the territory helps enterprises to update products more often, reduce their cost, i.e. use these competitive properties of the place to strengthen their competitiveness. It is proved that competitive advantages can be understood as the competitive potential of the region, which provides the possibility of its additional development by increasing the demand of the territory in conditions of free competition. It is substantiated that the competitive potential of the region is a set of competitive advantages and attractive characteristics of the region, which contribute to the efficient use of available and external resources, and distinguish the region among other actors in terms of its opportunities for effective socio-economic development. Practical meaning. Generalizations of features and forms of competition of regions can be used by scientists, teachers and students. Prospects for further research. Study of ways of development of territorial competition and methods of stimulation of regions for increase of their competitive attractiveness.

\footnotetext{
${ }^{1}$ Admiral Makarov National University of Shipbuilding, Kherson Branch; Associate Director for Education and Research; ORCID ID: https://orcid.org/0000-0003-0693-8000; e-mail: management@nuos.edu.ua.
} 
Keywords: business process, competition, competitive development of territories, scientific and innovative potential, interterritorial competition.

JEL Classification: M10; M13; R00; R58

Number of references: 15; number of tables: 1; number of figures: $\mathbf{0}$; number of formulas: $\mathbf{0}$.

\title{
Управління бізнес-процесами в системі забезпечення конкурентного розвитку територій: теоретичний аспект
}

\author{
Ірина Ігорівна Надточій ${ }^{1}$, к. е. н., доцент
}

Стаття надійшла: 10.05.2020 Стаття прийнята: 14.06 .2020
Nadtochii I. I. Business process management in the system of competitive development of territories: theoretical aspect. Економічні горизонти. 2020. № 2(12). C. 63-71. DOI: $10.31499 / 2616-5236.2(13) \cdot 2020.234986$

Анотація. Метою статті $\epsilon$ дослідження теоретичних основ управління бізнеспроцесами в системі забезпечення конкурентного розвитку територій. Методологія. Теоретичною і методологічною основою дослідження $\epsilon$ наукові праці вчених у дослідженні системи управління бізнес-процесів в системі забезпечення конкурентного розвитку територій. Для досягнення поставленої в роботі мети були використані такі методи дослідження: теоретичне узагальнення - особливостей та форм конкуренції регіонів; методи позитивного і нормативного аналізу - для визначення поняття «конкурентний потенціал регіону». Результати. Визначено, що проблеми міжрегіональної конкуренції висока та постійно зростає, є безліч білих плям в теорії осмислення особливостей та способів оцінки конкурентних властивостей та конкурентного потенціалу окремих суб'єктів територіального розвитку, нечіткі для розуміння способи та шляхи використання оцінок конкурентної привабливості в управлінні. Недостатньо є вивченими способи розвитку територіальної конкуренції та методи стимулювання регіонів для підвищення їх конкурентної привабливості. Доведено, що науковий та інноваційний потенціал та механізми їх підтримки - це найсучасніше та найперспективніше джерело конкурентних переваг. Визначено, що найбільш розвинені країни намагаються нарощувати у себе науковий та інноваційний потенціал, тому що він $є$ чинником створення принципово нових продуктів оновлення та підвищення якості товарів, що випускаються, винайдення нових технологій для підвищення продуктивності праці та зниження витрат ресурсів. Науковий та інноваційний потенціал території допомагає підприємствам, частіше оновлювати продукцію, знижувати її собівартість, тобто використовувати ці конкурентні властивості місця для зміцнення своєї конкурентоспроможності. Доведено, що конкурентні переваги можна розуміти як конкурентний потенціал регіону, що забезпечує можливість його додаткового розвитку за рахунок збільшення затребуваності території в умовах вільної конкуренції. Обгрунтовано, що конкурентним потенціалом розвитку регіону це сукупність конкурентних переваг та привабливих характеристик даного регіону, які сприяють ефективному використанню наявних та залученню зовнішніх ресурсів, та виділяють регіон серед інших суб’єктів конкуренції за його можливостям для ефективного соціально-економічного розвитку. Практичне значення. Узагальнення особливостей та форм конкуренції регіонів можуть бути використані науковцями, викладачами та студентами. Перспективи подальших досліджень. Вивчення способів розвитку територіальної конкуренції та методів стимулювання регіонів для підвищення їх конкурентної привабливості.

Ключові слова: бізнес-процес, конкуренція, конкурентний розвиток територій, науковий та інноваційний потенціал, міжтериторіальна конкуренція.

\footnotetext{
${ }^{1}$ Національний університет кораблебудування імені адмірала Макарова, Херсонська філія; заступник директора з навчально-методичної та наукової роботи; ідентифікатор ORCID: https://orcid.org/00000003-0693-8000; e-mail: management@nuos.edu.ua.
} 
Кількість джерел: 15; кількість таблиць: 1; кількість рисунків: 0; кількість формул: 0.

\section{Introduction.}

Competitiveness research issues are important and relevant both for the country's economy as a whole and for individual producers. In market conditions, high competitiveness of business entities is the key to obtaining high and stable profits. High competitiveness is the main condition for the development and vital activity of territories. Therefore, the theoretical foundations of business process management in the system of competitive development of territories in modern conditions are quite relevant.

\section{Literature review.}

Among modern specialists-economists, whose researches are devoted to problems of management of business processes in system of maintenance of competitive development of territories, it is necessary to note scientific works, in particular: M. Porter (1990; 1998), R. Hartman (2002), R. Fatkhutdinov (2005), N. Kostyleva (2005), A. Borisov (2006), M. Bodrikov (2009), D. Sepik (2011), I. Kramarenko (2014) T. Sachuk (2014), A. Sukhanova (2015), M. Voynarenko (2019), and others. However, the complexity and versatility of this study requires the study of the theoretical foundations of business process management in the system of competitive development of territories.

\section{Methodology.}

The theoretical and methodological basis of the study are the scientific works of scientists in the study of business process management in the system of competitive development of territories. To achieve the goal set in the work, the following research methods were used: theoretical generalization - features and forms of competition of regions; methods of positive and normative analysis - to define the concept of "competitive potential of the region".

\section{Research objectives.}

The purpose of the article is to study the theoretical foundations of business process management in the system of competitive development of territories.

\section{Results and discussions.}

Competition - struggle, rivalry in an industry - is one of the forms of interaction of market economy entities in the process of realization of their individual economic interests. In economics, competition is understood quite broadly. This is not only a competition for sales of goods and services, but also a struggle for raw materials, innovation, skilled labor and, on the other hand, competition for workers for better jobs. In the Great Economic Dictionary economic competition is interpreted as competition between economic entities: the struggle for markets for goods in order to obtain higher incomes, profits and other benefits.

The Dictionary of Modern Economic Terms emphasizes that competition is a civilized, legalized form of struggle for existence and one of the most effective mechanisms for selection and regulation in a market economy (Raizberg, Lozovskii and Starodubtseva, 2010).

However, these definitions and generalizations do not cover a special area of competition - competition of territories, regions for better, fuller involvement of their territorial space, natural and socio-economic potentials in national and global economic development. Given this expansion of the concept, we can say that economic competition is a competition between economic entities for markets for goods, markets for consumption of limited resources, for more efficient use of their potential to earn a living, income, profit or social benefits. The following components of economic competition can be identified:

- is the interaction in the production of goods and services;

- it is a competition for the ability to better, more efficiently perform certain functions or produce goods;

- is the competition for resources 
necessary for the production of goods and services or life;

- is a competition in the sale of their goods and services with other manufacturers;

- is a competition for attracting producers of goods and services to its territory.

To clarify the essence of the concept and features of the mechanisms of competition of the territory, we consider the differences between competition in the production of goods and services from the competition of regions in the socio-economic space of the country. Competition of the territory is considered by many researchers as competition of the commodity producers located in a certain territory. For example, Porter M. considers the competitive advantage of locations as a source of the highest productivity when firms use all factors and territorial advantages (Porter, 1998).

But the competition of the territory can also act as a competition of the subjects of territorial development for the successful implementation of the territorial space and the provision of territorial socio-economic resources to potential consumers. The difference in the subject of competition is that the company can sell its products, freely moving it in the regions of the country or the world. And the subject of competition of subjects of territorial development are the resources located in the territory which cannot be moved to other territory. The subject of industrial competition are enterprises in the vast majority of private forms of ownership, which are independently responsible for the success of their activities and can be declared bankrupt and liquidated. Territorial competition is territorial authorities, which are inseparable from the state and in any case must be supported by them in case of low competitiveness. Thus, a large part of the regions of Ukraine due to their low competitiveness and inability to ensure the livelihood of the population on their territory receive subsidized support for the development of social sphere and infrastructure, and often for "keeping afloat" enterpris- es in this area. With the advent of market relations in our country in the early 90 's, there was a need to understand the rights and freedoms that territorial authorities have to conduct an active local socio-economic policy.

To do this, consider the features and patterns of competitive relations between the subjects of territorial development in a planned economy and in modern market conditions. Thus, in a planned economy, the construction of new enterprises or infrastructure facilities was carried out only with partial consideration of the interests of future production and often proceeded from the political and economic feasibility of the development of individual territories. Currently, the freedom to choose the location is increasingly on the side of the investor, the owner of a particular enterprise and depends on how promising in terms of production development and profit is the area. From this moment, there are competitive relations of the territories for the creation of favorable conditions for the placement of new enterprises. For the construction of enterprises, the investor usually considers several potentially possible and interesting regions of Ukraine, then weighs the advantages and disadvantages of each option, makes decisions independently, agreeing with local authorities if the projects do not require centralized financing or co-financing and can be implemented. decision only of territorial authorities.

The development of inter-territorial competition and regional independence will enable public authorities to use new tools and institutions of centralized management, including more effective implementation of global socio-economic policies and long-term strategic plans.

Thus, summarizing the above, it should be noted that the urgency of the problem of interregional competition is high and growing, there are many white spots in the theory of understanding the features and methods of assessing the competitive properties and competitive potential of individual territorial 
development entities. competitive attractiveness in management. The ways of development of territorial competition and methods of stimulating regions to increase their competitive attractiveness are insufficiently studied. In scientific and practical terms, the following problems remain unprocessed or poorly developed:

- the choice of indicators that accurately reflect the territorial competitiveness;

- reduction of multidimensional indicators into a dimensionless form;

- construction of consolidated indicators of competitiveness of territories for their further ranking and assessment of development dynamics;

- development of methods of interfactor analysis of competitive advantages of regions.

To analyze the competitive advantages of territorial development entities, it is necessary to determine what can be the source of their competitive advantages. The "buyers" of territories can be different groups of consumers who need territory for production, social, tourist, transport and logistics, management and other needs.

In the study of the subject of territorial competition, "economic buyers" of territories interested in the location of new enterprises and investment are considered. To this group it is necessary to add competition not only for new enterprises and new investments, but also a special kind of competition for the preservation of existing enterprises, especially if they are city-forming. This is the kind of "buyers" of the territory, for which it is necessary to compete with the subjects of government, especially in cities and regions with a monostructure of the economy. Competition for the preservation of existing industries is often not taken into account, which threatens to gradually reduce the activities of enterprises in the area, bankruptcy or departure to other regions or countries due to the failure of their local conditions. The idea of treating existing businesses as "regular customers" is that local authorities do not consider that already locat- ed consumers in their territory are permanent and cannot change their location due to deteriorating conditions in the area or the emergence of more favorable conditions elsewhere. Therefore, it is necessary to change the mentality of local authorities so that they focus on maintaining and developing existing production capacity and reducing obstacles to the functioning of existing industries.

Attracting new investors is a very difficult task, associated not only with the creation of attractive conditions, but also with the active marketing of potential locations for new businesses. Creating attractive conditions in regions, cities and rural settlements is also important for the local population.

Competitive advantages are sources, factors of competitive force of the territory. In the scientific literature there are various theories of factors of competitive advantage of the territory. Thus, M. Porter proposes a rhombus model as a model of competitive advantages (Porter, 1990). Ensuring the competitiveness of countries is carried out, according to $\mathrm{M}$. Porter, on the basis of the so-called "diamond rule", i.e. creating four basic prerequisites that the state tries to maintain for its economy: conditions for factors, demand, related and supportive industries, sustainable strategy, structure and rivalry.

These elements are closely interrelated, and the action of one of the components often depends on the state of the other three. To make regional development sustainable, it is necessary to create favorable conditions, such as a growth-friendly macroeconomic environment, job creation, social stability, a tax and legal system that encourages business development and job creation. Thus, in the work of D. Sepik 11 factors are proposed, which, according to the author, describe the competitive advantages of the territory (Sepik, 2011): clusters; human capital; existing enterprises and networks; innovations or regional innovation systems; management and institutional capacity; branch structure and type of enterprises; infrastructure in a broad sense; 
typology of regions and the level of integration of enterprises; internationalization and nature of foreign direct investment; geographical location; investment attractiveness. The author draws attention to the fact that the prerequisites for regional competitiveness are created at the national level.

In general, for modern conditions of development, we propose to consider 10 sources of competitive advantages of the territory.

In theoretical terms, indicators of competitive properties by source of geopolitical status can be:

- proximity to developed or developing regions of the country and the world;

- proximity to significant sources of demanded minerals;

- proximity to recreational resources or tourist attractions;

- military-strategic importance of the region;

- administrative status or status of the territory in the country or in the world;

- special climatic or geodetic conditions that distinguish this place from other locations of production, residence, visits.

The resources of the factors of production include labor resources, land, natural resources, commercial premises, providing production with electricity, water, heat, gas, sewerage and municipal treatment facilities.

Due to their special importance, scientific and innovative potential, transport and information infrastructure, and financial capital have been removed from the group of "resources of factors of production" into separate groups. This is due to the fact that the name of the group of factors is currently a special concern of the region in its strategic development and are in demand from consumers. The importance of competitive advantages on these factors is of particular importance in transforming the regional structure of the economy in the direction of modern, innovative and informational.

It should be borne in mind that the current demand for competitive factors of pro- duction is increasingly shifting from universal (land, labor, energy, raw materials) to specific and highly specialized.

Regarding the factor "economic structure development, specialization and cooperation, clusters": a modern, rather high-tech enterprise cannot exist separately, because it will be very expensive. It is expected to be located in or near a large city to be able to cooperate with other companies and use various services of financial, legal and administrative structures.

Scientific and innovative potential and mechanisms for their support are the most modern and promising source of competitive advantages. The most developed countries are trying to increase their scientific and innovative potential, because it is a factor in creating fundamentally new products to upgrade and improve the quality of products, inventing new technologies to increase productivity and reduce resource costs. The scientific and innovative potential of the territory helps enterprises to update products more often, reduce their cost, ie use these competitive properties of the place for strengthen their competitiveness.

Transport and information infrastructure are very important for the development of any region. Here it is necessary to assess the internal transport and information infrastructure, which is necessary for the effective functioning of the socio-economic complex of the region or city, as well as external, intercity and interregional infrastructure.

Regarding the group of factors "Demand potential for goods and services, domestic and foreign consumers": regions that have significant potential for consumer demand (meaning not only the population but also enterprises), have significant attractiveness for both trade and production goods and services.

Living conditions are one of the most significant sources of competitive advantage, the higher the quality of life, the more interesting the region for residents, migrants, stu- 
dents and tourists. For companies, it also has economic and social significance. When choosing a place for a new company, foreign investors must take into account the living conditions of managers and specialists who will come from the investor's country.

Effective management on the territory is a powerful source of competitive advantage.

Cultural, historical and tourist potential provides special competitive advantages of economic and social nature, which affects the interests of residents and tourists, provides a significant inflow of income into the region. This also has a certain significance for attracting investments in the creation of enterprises.

Good environmental conditions are an important competitive advantage for the population of most consumers in the area, although production is not always interested in increasing the cost of environmental protection, because it increases the cost of production. However, such enterprises may also benefit from increased environmental requirements, because it encourages them to develop innovations and save resources, upgrade products, improve its quality.

According to the theory of competitiveness of nations proposed by $\mathrm{M}$. Porter, the key factors in the formation of competitive advantages are factor conditions, demand conditions, the activities of related industries and strategies of individual enterprises. Accordingly, the competitive growth of the country and a particular region should be divided into four stages: (1) the stage of factors; (2) the stage of investment; (3) the stage of innovation; (4) the stage of wealth. The globalization of the world economy is changing the requirements for the formation of competitive advantages, as a significant amount of means of production, information and financial resources, human resources due to migration processes, market conditions are constantly changing, many world leaders are losing their positions, new global production centers are being formed. assortment groups of goods and services (Porter, 1998).
Highly competitive properties of the region provide additional inflow of development resources (capital, labor resources, etc.) and increase their efficiency. Therefore, it can be assumed that the competitive advantages of the region allow to attract more resources for development or contribute to the growth of results per unit of resources. The development of the innovation sphere is also a competitive advantage, because it contributes to the growth of labor productivity and the achievement of social results, ie competitive advantages are a general condition for the development of the region.

Given the above, competitive advantages can be understood as the competitive potential of the region, which provides the possibility of its further development by increasing the demand for the territory in conditions of free competition. We consider the competitive potential of the region's development to be a set of competitive advantages and attractive characteristics of the region, which contribute to the efficient use of available and external resources, and distinguish the region among other competitors in terms of its opportunities for effective socio-economic development.

For the territories of Ukraine seeking to increase their competitiveness in national and global markets, the choice of business region formation strategy requires the creation of special management mechanisms that ensure effective use of existing socio-economic potential and mastering the methods of network interaction. To solve this problem, there are three conditional forms of competition of regions and their corresponding forms of competitiveness, representing certain subjectobject relations and relations in different conditions of regional economic development. These are: economic competition; spatial competition; network competition (Voynarenko, 2019). The specifics and features of the forms of competition of the regions are presented in Table 1. 
Table 1. Features and forms of competition of regions

\begin{tabular}{|l|c|c|c|}
\hline \multicolumn{1}{|c|}{ Characteristics } & \multicolumn{3}{|c|}{ Forms } \\
\cline { 2 - 4 } & Economic competition & Spatial competition & Network competition \\
\hline $\begin{array}{l}\text { The subject of } \\
\text { competition }\end{array}$ & Large enterprises & Regional authorities & $\begin{array}{c}\text { Regional networks of } \\
\text { government and business }\end{array}$ \\
\hline Object of competition & $\begin{array}{c}\text { Costs and profits of } \\
\text { enterprises }\end{array}$ & $\begin{array}{c}\text { Competitive advantages } \\
\text { of the territory }\end{array}$ & $\begin{array}{c}\text { Public and private } \\
\text { investments }\end{array}$ \\
\hline Competition goals & $\begin{array}{c}\text { Growth in production } \\
\text { of goods and services }\end{array}$ & $\begin{array}{c}\text { Creating favorable living } \\
\text { conditions and creating a } \\
\text { business }\end{array}$ & $\begin{array}{c}\text { Capitalization of the } \\
\text { region }\end{array}$ \\
\hline Factors of competition & $\begin{array}{c}\text { Natural, financial, } \\
\text { labor, etc. }\end{array}$ & $\begin{array}{c}\text { Natural, financial, labor, } \\
\text { etc. }\end{array}$ & $\begin{array}{c}\text { Flows of capital, goods } \\
\text { and resources }\end{array}$ \\
\hline $\begin{array}{l}\text { The nature of regional } \\
\text { policy }\end{array}$ & Industrial & Alignment policy & $\begin{array}{c}\text { Innovative and structural } \\
\text { Instruments of } \\
\text { regional policy }\end{array}$ \\
\hline
\end{tabular}

Source: Sukhanova (2015); Irtyshchevaet al. (2020); Pryshchepa et al. (2020).

In modern conditions of socio-economic development, Ukrainian regions are involved in all three forms of competition. Therefore, given the specifics of regional development, the main task of the authorities is to implement socio-economic policy that allows to create and develop competitive advantages that shape spatial and network competitiveness by stimulating network interaction of regions as a necessary condition for creating business regions. Of particular importance is the formation of financial factors of competitiveness (Sukhanova, 2015). Reengineering offers to move from an outdated organization of work to process management - a set of steps that begins with one or more inputs and ends with the creation of services that the client needs. The purpose of each business process is to offer the customer a product or service that would satisfy him in cost, quality and service (Kramarenko, 2014).

Currently, the direction of economic axiology is actively developing, the founder of which is defined as R. Hartman (2002). Domestic researchers A. Mazaraki, V. Yeremenko, J. Legkun and others note the need to take into account the theory of value in the context of the formation of the competitiveness of the product, enterprise and region and foreign
A. Subetto, A. Palmer and others (Bodrikov, 2009). R.A. Fatkhutdinov's approach is wellfounded, which determines that the basis of competitive advantages is a certain unique value possessed by the object, which gives it an advantage over competitors (Fatkhutdinov, 2005).

\section{Conclusions.}

It is determined that the problems of interregional competition are high and constantly growing, there are many white spots in the theory of understanding the features and methods of assessing the competitive properties and competitive potential of individual territorial development entities, unclear ways and means to use assessments of competitive attractiveness in management. The ways of development of territorial competition and methods of stimulating regions to increase their competitive attractiveness are insufficiently studied.

It is proved that the scientific and innovative potential and mechanisms of their support are the most modern and promising source of competitive advantages. It is determined that the most developed countries are trying to increase their scientific and innovative potential, because it is a factor in creating fundamentally new products to upgrade and 
improve the quality of products, inventing new technologies to increase productivity and reduce resource costs. The scientific and innovative potential of the territory helps enterprises to update products more often, reduce their cost that is use these competitive properties of the place to strengthen their competitiveness.

It is proved that competitive advantages can be understood as the competitive potential of the region, which provides the possibil- ity of its additional development by increasing the demand of the territory in conditions of free competition. It is substantiated that the competitive potential of the region is a set of competitive advantages and attractive characteristics of the region, which contribute to the efficient use of available and external resources, and distinguish the region among other actors in terms of its opportunities for effective socio-economic development.

\section{References}

Bodrikov, M. (2009), “Classical theory of value: Modern sounding of unsolved problems”, Voprosy Ekonomiki, no. 7, pp. 97-118, doi: https://doi.org/10.32609/0042-8736-2009-7-97-118

Borisov, A. B. (2006), Bol'shoi ekonomicheskii slovar' [Large economic dictionary], Book World, Moscow, Russia, 543 p.

Fatkhutdinov, R. A. (2005), Strategicheskaya konkurentosposobnost' [Strategic competitiveness], Ekonomika, Moscow, Russia, $512 \mathrm{p}$.

Hartman, R. S. (2002), Knowledge of good: Critique of axiological reason, Brill Rodopi, Amsterdam / New York, $484 \mathrm{p}$.

Irtyshcheva, I., Kramarenko, I., Shults, S., Boiko, Y., Blishchuk, K., Hryshyna, N., Popadynets, N., Dubynska, I., Ishchenko, O. and Krapyvina, D. (2020), "Building favorable investment climate for economic development", Accounting, vol. 6, issue 5, pp. 773-780, doi: http://dx.doi.org/10.5267/j.ac.2020.6.006

Kostyleva, N. E. (2005), Innovatsionnye metody povysheniya konkurentosposobnosti gorodov i regionov [Innovative methods to increase the competitiveness of cities and regions], IRE RAN, S. Petersburg, Russia, 243 p.

Kramarenko, I. S. (2014), Reinzhynirynh navchalnoho protsesu: vid teorii do praktyky [Reengineering of the educational process: From theory to practice], FOP Shvets VD., Mykolaiv, Ukraine, $64 \mathrm{p}$.

Porter, M. E. (1990), “The competitive advantage of nations”, Harvard Business Review Press, March-April, pp. 74-91.

Porter, M. E. (1998), On competition, Harvard Business Publishing, Brighton, USA, 485 p.

Pryshchepa, O., $\quad$ Kardash, O., $\quad$ Yakymchuk, A., $\quad$ Shvec, M., $\quad$ Pavlov, K., $\quad$ Pavlova, O., $\quad$ Irtyshcheva, I., Popadynets, N., Boiko, Y. and Kramarenko, I. (2020), "Optimization of multi-channel queuing systems with a single retail attempt: Economic approach”, Decision Science Letters, vol. 9, issue. 4, pp. 559-564, doi: http://dx.doi.org/10.5267/j.dsl.2020.8.002

Raizberg, B. A., Lozovskii, L. Sh. and Starodubtseva, E. B. (2010), Sovremennyi ekonomicheskii slovar' [Dictionary of modern economic terms], 5th ed., Infra-M, Moscow, Russia, 512 p.

Sachuk, T. V. (2014), Territorial'nyi marketing [Territorial marketing], Piter, S. Petersburg, Russia, 368 p.

Sepik, D. (2005), Konkurentosposobnost' regionov: nekotorye aspekty [Competitiveness of regions: Some aspects], Russian-European Center for Economic Policy, Moscow, Russia, 42 p.

Sukhanova, A. V. (2015), "Competitive advantages and strategy of regions in a set of competitiveness relations", Investments: practice and experience, no. 21, pp. 103-107.

Voynarenko, M. P. (2019), “Trends and prospects for the development of regional clusters' capacity in a society's digitalization”, Rehionalna ekonomika, no.4, pp. 28-35, doi: https://doi.org/10.36818/15620905-2019-4-2

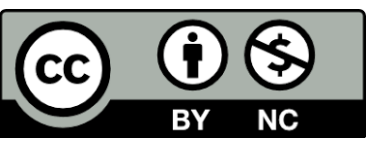

Цей твір ліцензовано на умовах Ліцензії Creative Commons «/з Зазначенням Авторства = Некомериійна 4.0 Міжнародна» (CC BY-NC 4.0).

This is an open access journal and all published articles are licensed under a Creative Commons "Attribution-NonCommercial 4.0 International" (CC BY-NC 4.0). 